\title{
Balancing private and state ownership in emerging markets' telecommunications infrastructure: country, industry, and firm influences
}

Jonathan P Doh, Hildy Teegen and Ram Mudambi
Journal of International Business Studies (2004) 35, 459. doi: I 0. I 057/palgrave.jibs.8400 I 05

Correction to: Journal of International Business Studies (2004) 35, 233-250. doi: 10.1057/palgrave.jibs.8400082

Owing to a production error the author biographies that should have appeared in the above paper were not published. The biographies appear below. We apologise to the authors for this oversight.

\section{About the authors}

Jonathan Doh is Assistant Professor of Management and Director of the Center for Responsible Leadership and Governance at Villanova University, Senior Associate at CSIS, and executive professor at GSBA-Zurich. Previously, he was on the faculty of American and Georgetown, and a trade official with the US government. He has authored more than 35 articles and chapters on international management and recently co-edited (with Hildy Teegen) the volume Globalization and NGOs (Praeger, 2003).

Hildy Teegen is Associate Professor of International Business and International Affairs at George Washington University. Previously, she was on the faculty of the College of William and Mary. She has published widely in the areas of cross-border alliances, international negotiations, international exporting, and economic sanctions. She is editor (with Jonathan Doh) of Globalization and NGOs (Praeger, 2003).

Ram Mudambi is Associate Professor in the Department of General and Strategic Management at the Fox School, Temple University. He has published over 40 refereed journal articles and authored or edited six books. Prior to joining Temple, Ram taught at Case Western Reserve, University of North Carolina, University of Reading, and University of Buckingham. He retains a visiting appointment at the International Securities Market Association Centre at the University of Reading. 